\title{
STUDYING ADOPTION OF CRYPTOCURRENCIES AND BLOCKCHAIN TECHNOLOGY IN THE BALTIC STATES
}

\author{
(iD Natalija Kostrikova ${ }^{1}$, MBA
}

1 Latvia University of Life Sciences and Technologies

\begin{abstract}
The paper aims to analyse adoption of cryptocurrencies and blockchain technology in the Baltic States in the context of regional competitiveness. To achieve the aim, the following tasks are set: 1) to investigate crypto activity and crypto regulation, 2) to analyse blockchain applications and policy actions beyond crypto space, 3) to investigate interconnections between blockchain adoption and regional competitiveness. The study employs methods of descriptive statistics and content analysis. The study concludes that Estonia's leadership in the majority of regional competitiveness indicators correlates with its leading position in blockchain adoption not only in Baltic States, but also worldwide, specifically in the area of e-government. Lithuania shows an overall competitive position in blockchain adoption in fintech area. In contrast, Latvia significantly lags behind Estonia and Lithuania in terms of regional competitiveness and adoption of blockchain technology, which is weakened by the regulatory unclarity for virtual asset service providers and the lack of supportive actions from the government for blockchain innovation and its further adoption within and beyond cryptospace.
\end{abstract}

Key words: blockchain technology adoption, cryptocurrencies, virtual assets.

JEL code: $\mathrm{O} 33$

\section{Introduction}

The most prominent use case of blockchain technology implementation up to date are cryptocurrencies and virtual assets, however blockchain technology applications span far beyond crypto space with disruptive and transformational effects on transactional relationships in digital environment. Hence, blockchain technology is seen by various scholars as a general-purpose technology (Yli-Huumo et al., 2016) an institutional technology (Davidson et al., 2018) and a foundational technology (Iansiti and Lakhani, 2017) due to its potential capabilities to transform economic models and public administration functions.

The EU Digital Single Market Strategy aims to improve access to digital goods and services, forming an environment in which digital networks and services can thrive and increasing the level of digital skills that are necessary for a comprehensive digital society (A Digital Single..., 2015). Under its framework a European Blockchain Strategy was developed by the European Commission, which underlines that blockchain is a transformative technology for Europe as it has potential to revolutionise data sharing practices, transform industries and cross-border public services, create a citizen-centric digital society and contribute to the economy through creating jobs and bringing economic value (European Blockchain Strategy..., 2021). Policy actions and activities include financing of blockchain innovation and start-ups, creating political partnerships across EU member states through the European Blockchain Partnership, promoting a pan-European legal certainty, contributing to international blockchain standards, supporting blockchain skills development of Europe's citizens and interacting with the community (European Blockchain Strategy..., 2021).

Given the political agenda of the European Union, it is important to study if blockchain adoption correlates with the level of regional competitiveness. Wintjes and Hollanders (2020) see that region's competitive position is dependent on the following factors:

- Accessibility to knowledge;

- Capacity to absorb knowledge;

- Capacity to diffuse knowledge and technology.

1 kostrikova.natalia@gmail.com 
This paper aims to study interconnections between blockchain adoption and regional competitiveness in the Baltic States. For that, it is necessary to analyse blockchain adoption pace in the Baltic States in the area of cryptocurrencies and beyond and its relation to regional competitiveness. This paper applies methods of descriptive statistics for outlining crypto-activity and regional competitiveness indicators and content analysis for describing blockchain applications in each country and analysing interconnections with regional competitiveness.

\section{Research results and discussion}

\section{Analysis of crypto-activity in the Baltic States}

As demonstrated by the figure 1 funds raised through initial public offerings (ICOs) in Estonia and Lithuania are considerably bigger than in Latvia.

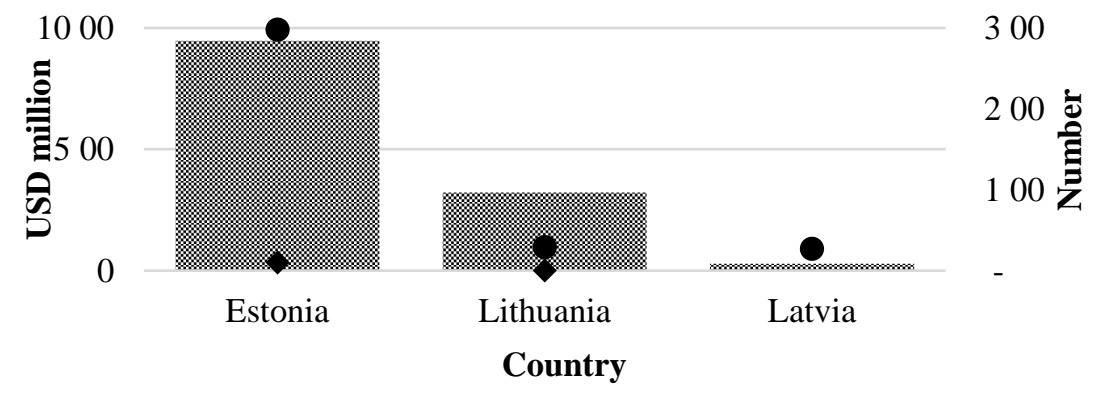

Source: author's construction based on data from Stats and Facts..., 2020; List of All..., 2020

Fig. 1. Crypto activity in the Baltic States

In global rating Estonia takes the $7^{\text {th }}$ place, Lithuania takes the $11^{\text {th }}$ place and Latvia takes the $34^{\text {th }}$ place by ICO funds raised (Stats and Facts..., 2020), which reflects that Latvia considerably lags behind Estonia and Lithuania. Although in terms of number of ICOs Lithuania and Latvia are on the same level with 29 and 27 ICOs accordingly, Lithuanian crypto entrepreneurs have been far more successful than Latvian entrepreneurs and have managed to attract ca. 10 times more funds through ICOs (USD 323 million and USD 28 million accordingly). Crypto activity correlates with cryptoregulatory ranks of both countries Lithuania takes the $4^{\text {th }}$ place in the world, whilst Latvia takes only $81^{\text {st }}$ place (Blockchain Regulations..., 2020).

Interestingly, Estonia takes after Lithuania with the $14^{\text {th }}$ place according to cryptoregulatory ranking, however it attracted ca. 3 times more funds through ICOs (USD 946 million) and conducted ca. 10 times more ICOs (298). In Estonia, activities with cryptocurrencies and virtual assets require a specialized license since 2017. In Lithuania, activities with cryptocurrencies and virtual assets require a specialized license since 2019. In Latvia, no license is required to conduct activities with cryptocurrencies and virtual assets, which indicates regulatory uncertainty in Latvia comparing to other Baltic countries, hence, a lower cryptoregulatory rank. In all three countries virtual asset service providers must comply with the relevant European and national regulations on anti-money laundering and prevention of terrorist financing.

Estonia also shows leadership in the number of crypto exchanges in the Baltic States - 34 crypto exchanges in comparison to only one in Lithuania and none in Latvia (List of All..., 2020). This tendency can be explained by the fact that Estonia was the first country in the Baltic States, which started to actively attract crypto projects by utilizing its digital nation image. Estonia responded very quickly to new trends and increasing interest in cryptocurrencies and was one of the first countries in the world to introduce crypto regulation. Due to the full digitalisation of public services and the launch of the E-residence program 
in 2014, which allowed digital entrepreneurs to start and run an online business remotely (The New Digital..., [n.y.]), incorporating a company operating with cryptocurrencies in Estonia was possible remotely from anywhere in the world. Due to low competition in the world at that time, almost 1300 cryptocurrency licenses were issued in Estonia by 2019 (Estonian Financial Intelligence Unit, 2019).

Estonia was also the first country in Baltic States to introduce respective ICO guidelines hence benefitting from early ICO activities. Financial regulator in Estonia published ICO guidelines in 2016, whilst Lithuania and Latvia published them only in 2017 and 2019, accordingly. ICO guidelines outline explanations in which cases tokens issued through ICOs would not require a specialized authorisation from the financial regulator and in which cases tokens would be classified as financial instruments and, hence, must be compliant with relevant regulations such as co-investment, financial securities or crowd-funding laws.

\section{Analysis of blockchain adoption beyond crypto space in Estonia}

Estonia differentiates between blockchain technology application in crypto space and beyond, specifically within e-government services. A national digitalization policy serves as the basis for adoption of blockchain technologies in Estonia. For example, in 2007 an electronic voting and in 2014 an e-Residence programme were launched. Hence, a blockchain technology logically continues the overall digitalisation policy of the state. In addition, following a cyber attack on government data repositories in 2007, Estonia developed a cyber security strategy and a cryptographic algorithm Keyless Signature Infrastructure (KSI), which was later integrated with blockchain technology and used in several Estonian e-government services (Security and Safety..., [n.y.]).

Blockchain technology has been used in Estonian e-government systems since 2012 and is currently being implemented in six government registers: the health care register, the property register, the business register, the succession register, the digital court system and the state newspaper (PwC, 2019). Interoperable databases of the national data exchange layer X-Road are being gradually secured using blockchain technology, adding an extra layer of security to the system. Within the Estonian e-government systems blockchain technology ensures the integrity of data, systems, and processes, as well as the control and verification of data generation time.

For the Registry and Information Systems Centre (RIK), which provides a digital environment for integrated e-government services in Estonia, the main value added of blockchain technology is the ability to check large amounts of data regularly and quickly and to ensure that there have been no malicious data changes. As a result, national registries become faster and more efficient because there is no intermediary in data exchange. Hence, the RIK can channel its resources to the control of the system instead of acting as intermediary. The likelihood of fraud discovery also increases.

The EU Agency for large-scale IT systems and the NATO Cooperative Centre for Excellence in Cyber Defence are based in Tallinn, which indicates Estonia's global and European leadership in digitalization and cybersecurity aspects. In addition, Estonia is considered to be one of the most advanced users of blockchain technology in Europe in the provision of public services with the aim of increasing cyber security and process transparency.

The best-known blockchain technology developer in Estonia is Guardtime, which operates since 2007 and developed a KSI algorithm, which was subsequently integrated with blockchain technology and is currently being deployed by a number of e-government registries. In a nutshell, a KSI blockchain implements large-scale data authentication without the need for a centralized authority. In 2016, the 
Guardtime project announced a partnership with the E-Health Foundation aiming to protect medical records (Blockchain Startup to..., 2016).

In 2015, Estonian government e-Residency program in partnership with Bitnation project piloted blokchain-based public notary services for e-residents, including birth certificate, marriage registration, and some commercial contracts (Bitnation to Offer..., 2015). Bitnation notary services can be used from anywhere in the world.

Blockchain technology experimentation took place also in the financial services sector. For instance, an LHV Bank in partnership with ChromaWay piloted the Cuber Wallet, which operated based on the open protocol of Coloured Coins rooted in the Bitcoin blockchain. Cuber Wallet allowed users to store private keys on their smart devices as well as sending and receiving EUR transfers instantly and without any commission.

AS Eesti Väärtpaberikeskus, which belongs to the NASDAQ OMX Group, piloted a blockchain-based evoting system for shareholders' meetings in Estonia, enabling shareholders to participate in the voting process remotely.

Estonia also intended to launch its blockchain-based digital currency, Estcoin, in a form of cryptocurrency, so that e-residents could invest directly in Estonia with the aim of increasing trust in blockchain technology. However, the the European Central Bank forbid this initiative because the only legal currency in the Eurozone is the euro.

Estonia has all the prerequisites to integrate the entire national IT infrastructure with blockchain technology - high development of digital economy, high public trust in e-services, experience in development of state e-government services, X-Road data exchange layer, ICT knowledge, small population and widely used identification through ID cards. Existing e-government solutions already allow Estonia to save up to $2 \%$ of GDP per year (European Parliament..., 2017).

\section{Analysis of blockchain adoption beyond crypto space in Lithuania}

The Bank of Lithuania facilitates blockchain technology innovation and adoption in the field of fintech. In 2018, the Bank of Lithuania introduced a pilot project of an LBChain Sandbox (LBchain..., 2020) in order to establish a technological foundation for fintech start-ups to develop and test blockchain-based applications in the digital environment, which is monitored and managed by the Bank of Lithuania.

The projects that participated in the first pilot stage of the LBChain project included a blockchain platform for green bonds issuance, a blockchain-based regulatory reporting solution and a blockchain-based digital bank. At all three stages, 11 fintech start-ups from 8 countries implemented blockchain simulation in a regulatory environment managed by the Bank of Lithuania. After three phases of experimentation, the LBChain project was officially launched in the fourth quarter of 2020.

Adamonis (2020), LBChain's project manager notes that based on feedback received from financial institutions, the Bank of Lithuania focused its piloting activities within the LBChain project on permissioned blockchain systems rather than on public blockchains, therefore the LBChain was built on the basis of Corda and Hyperledger Fabric.

As a result, the LBChain project facilitated cooperation with educational institutions, attracted foreign investment and expanded technological capabilities of the Bank of Lithuania through blockchain-based integrations. It also shows the clear desire of the Bank of Lithuania to attract more international blockchain start-ups, facilitate cooperation between private and public sectors and raise public awareness about blockchain-based solutions. Govina (2018), an executive director of the financial sector supervision service at the Bank of Lithuania, underlines that awareness about crypto-currencies and demonstration of 
blockchain-based use cases in the field of fintech are pre-requisite for facilitating further adoption of blockchain technology in Lithuania.

Adamonis (2020) also mentioned that the Bank of Lithuania plans to start development of the LTChain - a blockchain-based platform for applications beyond the financial services sector. Within the LTChain project, the bank will work closely with other government institutions and will aim to attract non-fintech start-ups from such industries as healthcare, transportation and energy.

In addition to the rapid regulatory response and the LBchain initiative promoted by the Bank of Lithuania, it also attracts the attention of blockchain developers by issuing the world's first digital collection coin based on blockchains dedicated to the signing of the Lithuanian Independence Act, which happened on February 16, 1918 (Digital Collector Coin..., 2020).

The coin has a face value of $€ 19.18$ and has a rectangular shape similar to a credit card. The image of the coin consists of 36500 pixels - about the same number of days have passed since the Act was signed. It is planned to issue 24000 tokens, each of which will have a picture of one of the 20 signatories. The tokens will be divided into six activity categories with 4000 pixels each. Potential buyers will receive six tokens randomly. In order to receive a physical silver coin, they must collect tokens from all six categories. Although the coin is not a legal currency, it provides international visibility to the blockchain-based solutions developed in Lithuania, serves as a marketing tool for the Lithuanian blockchain ecosystem to attract global technology start-ups, and allows the Bank of Lithuania to test blockchain-based solutions in the field of fintech.

Moreover, the Vilnius Blockchain Centre was established in 2018 as a part of an international network with centres in Shanghai and Melbourne (About Us..., [n.y]). Apart from acceleration programs, co-working opportunities, blockchain community-building and education activities, it helps European blockchain startups to reach the Asian and Australian markets, and vice versa. Egle Nemeikstyte, Executive Director of the Vilnius Blockchain Centre, underlines that the Ministry of Finance of the Republic of Lithuania politically and practically supported this initiative, as it began with the creation of blockchain-based financial instruments in order to fund the project, which contributed to establishing legal certainty, which is significant for implementation of blockchain-based projects (Rukovoditel' blokchejn-centra ..., 2018).

\section{Analysis of blockchain adoption beyond crypto space in Latvia}

In 2018, the Ministry of Finance of the Republic of Latvia issued a report 'On adaptation of information systems for receipt and processing of electronic invoices for tax administration', in which it defined several proposals to promote adoption of blockchain technology in Latvia (Finansu Ministrija, 2018).

- It is important to develop a consistent vision and a national strategy for facilitating blockchain innovation and adoption, and a specialized system should be gradually developed on the basis of which transactions registered in the blockchain would be considered as legally valid.

- Support for IT companies operating in the blockchain field should be encouraged, but at the same time, the incorrect association of this IT field with cryptocurrencies and virtual assets and unjustified restrictions should be reduced.

- To assess the potential of blockchain technology in improving public administration services, to identify obstacles to the adoption of blockchain technology, to prepare proposals for support activities for blockchain technology and to establish an expert working group under the Ministry of Economics. One of the tasks of the working group would be to investigate these issues and to prepare proposals for the 
use of blockchain technology in the private and public sectors with the emphasis on efficiency and security aspects.

In 2019, the Ministry of Economics of the Republic of Latvia issued a report 'On examples of the use of blockchain technology, perspectives and further actions to promote the development of the field' with the aim to evaluate prospects of potential blockchain technology applications in the public sector, to formulate further activities to promote blockchain technology adoption in Latvia, as well as to evaluate legal and technological considerations referring to blockchain technology (Ekonomikas Ministrija, 2019).

In order to define potential blockchain technology applications in the public sector, a working group was established, which comprised of experts from various ministries, government agencies, industry associations and companies, including Latvian Blockchain Association. As a result of the working group's activity, two potential pilot projects were identified (Ekonomikas Ministrija, 2019):

- Register of Enterprises sees the added value of a blockchain technology in relation to the maintenance of the register of Limited Liability Companies' (SIA) participants as according to estimates there is around 25-30 thousand such cases per year.

- The Ministry of Economics sees the added value of a blockchain technology in relation to combatting shadow economy and considers development of a technical solution in cash registers and other devices for trade data transfer to the State Revenue Service (SRS) by applying a blockchain technology.

On 16 July 2020 the Ministry of Economics issued a report 'On possibilities of using blockchain technology in cash registers and other devices for the reduction of the shadow economy', mainly setting out economic rationale for potential blockchain technology integration with cash registers and other electronic devices (e.g. smartphones and other smart devices), which will likely be included in supervisory activities of the SRS. According to the Ministry of Economics, the development of such blockchain-based technical solution will allow for reliable online trade data transmission to the SRS and will considerably prevent data abuse and fraud and will serve in the objective interests of all parties (Ekonomikas Ministrija, 2020). At the same time, the Ministry of Economics acknowledges that Latvia does not have a clear vision on how to develop or purchase blockchain-based solutions, as well as no overall vision on adaptation of existing information systems in order to ensure their further compatibility with blockchain solutions (Ekonomikas Ministrija, 2020). Based on the considerations, described in the report, the Cabinet of Ministers decided that an inter-institutional working group, which in works on adaptation of information systems for receipt and processing of electronic invoices for tax administration within the framework of a cash registers reform should also consider the application of blockchain technology for data registration in cash registers and develop a concept solution by 1 March 2021.

The Ministry of Economics considers it necessary to update the discussion on the cash register reform to the technological solutions and IT infrastructure of the $21^{\text {st }}$ century, namely, solutions that would strengthen the SRS monitoring capabilities and ensure a proportionate financial and administrative burden to entrepreneurs in order to ensure compliance with the requirements set for them (Ekonomikas Ministrija, 2020). The potential solution is expected to reduce the shadow economy and the costs associated with the certification and maintenance of cash registers, as well as improve the ease of doing business through obtaining real-time tax data from merchants.

The Latvian Blockchain Association advocates for public policy to recognize the 'existence of cryptocurrencies and the role of the blockchain technology in the array of industries'. Although the association contributed to the first report of the Ministry of Economics issued in 2019, it has not yet resulted 
in definite public policies, support actions or regulations. As at the date of this study, 'consistent vision and national strategy', 'support for IT companies operating in the blockchain field', 'support activities for blockchain technology', 'proposals for the use of blockchain technology in the private and public sectors' mentioned in the Ministry of Finance (2018) have not yet been developed yet.

Since blockchain technology is a prominent technology applied in fintech innovations, it is important to see, if it is somehow supported by the financial regulator. Having analysed the available public information, it can be derived that there are no blockchain-specific support activities in the fintech field in Latvia, despite that strategic directions of the Financial Capital Markets Commission (FCMC) cover support for fintech solutions as well as promotion of financial system innovations through such instruments as innovation sandbox, which offers implementation of a specific testing plan agreed with the FCMC prior to the launch of a fintech solution (Innovation Sandbox, [n.y.]). In comparison to the blockchain sandbox created by the Bank of Lithuania, an innovation sandbox in Latvia does not offer a digital environment and is rather focused on simulation of a standard reporting process.

\section{Analysis of interconnections between blockchain technology adoption and regional competitiveness in the Baltic States}

The analysis outlined in previous sections concluded that the levels of adoption of blockchain technologies both in the crypto space and beyond are the highest in Estonia, followed by a globally competitive level of blockchain adoption in Lithuania (especially in the field of fintech) and a rather weak level of blockchain adoption in Latvia. It is therefore important to analyse the interrelationship with regional competitiveness indicators in order to understand the possible causes of such disparities and any associated economic consequences.

As the innovation and adoption processes of blockchain technologies are clearly based on the use of a knowledge resource supported by the concept of the knowledge economy and by empirical evidence of blockchain technology adoption models all over the globe, support for R\&D and education is likely to be linked to blockchain adoption. As shown in the figure 2, Estonia has the highest R\&D expenditure and public expenditure on tertiary education as a percentage of GDP, and Latvia has the lowest values.

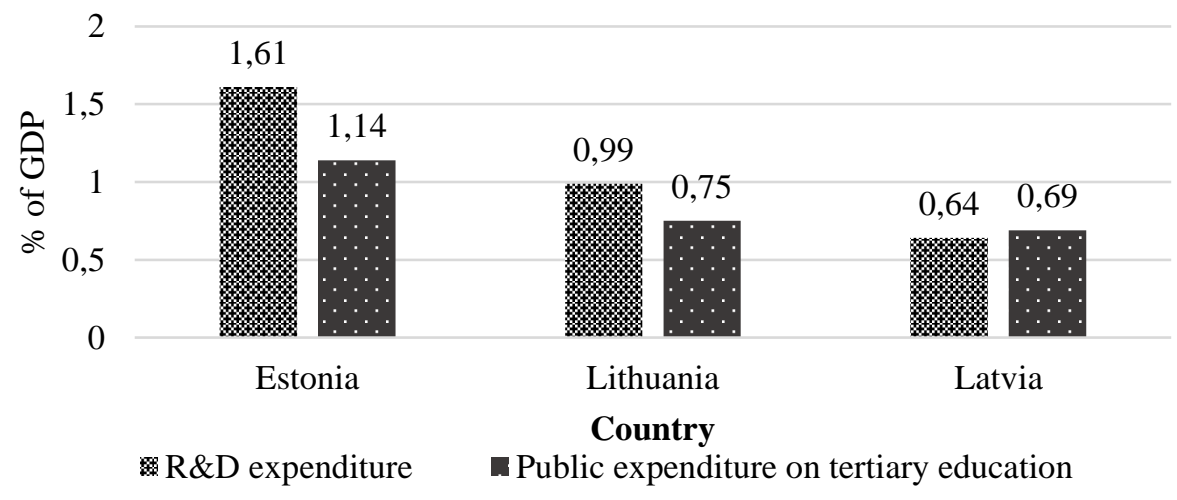

Source: author's calculations based on Gross Domestic Expenditure..., 2019; Public Expenditure on..., 2017

\section{Fig. 2. R\&D expenditure and public expenditure on tertiary education as \%} of GDP in the Baltic States

With regard to overall level of blockchain adoption in crypto space and other blockchain application areas a similar trend can be noticed, so the author considers that R\&D activities and education would have a rather logical link to blockchain adoption. However, the author also assumes that correlation does not yet mean causality, as many other factors may have a clearer effect on blockchain adoption, such as clear state policies and related practical support for blockchain innovation and adoption that exist in Estonia and 
Lithuania and do not exist in Latvia. As shown in figure 3, Estonia has the highest levels of e-government and e-participation in Baltic States, supported by its digitalisation policy actions, including application of a blockchain technology in e-government registers.

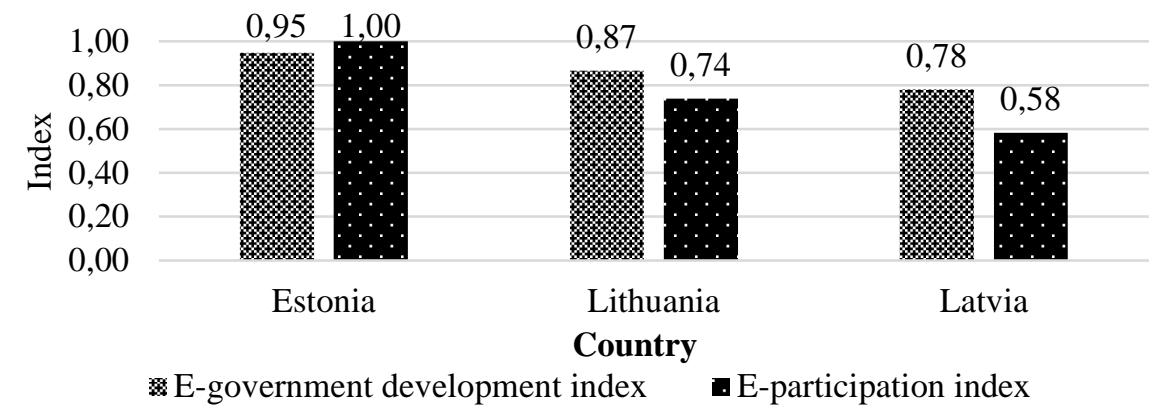

Source: author's calculations based on Country Data, 2020

Fig. 3. E-indices in the Baltic States

Thus, it can be concluded that the adoption of blockchain technology is directly related to the level of e-government and e-participation, as it is technologically able to create the necessary system of trust between government and citizens through ensuring efficient and secure data exchange procedures. It is possible to observe the digital progress of the Baltic states through the components of the Digital Economy and Society Index. As figure 4 shows, Estonia demonstrates the highest DESI index among three countries - 61.07 compared to 53.89 in Lithuania and 50.71 in Latvia, and the human capital component contributes the most to the difference.

\begin{tabular}{|c|c|c|c|}
\hline \multirow{4}{*}{$\begin{array}{l}\text { 40,00 } \\
20,00\end{array}$} & 134 & & \\
\hline & 10 & 22 & स 6 \\
\hline & 9,81 & 10.08 & 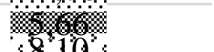 \\
\hline & $\$ 60$ & 108 & $8.0 \%$ \\
\hline \multirow{3}{*}{0,00} & $1 \dot{1} ; \dot{9} \dot{6}$ & 12,22 & 15,44 \\
\hline & Estonia & Lithuania & Latvia \\
\hline & & \multicolumn{2}{|l|}{ Country } \\
\hline \multirow{2}{*}{\multicolumn{2}{|c|}{$\begin{array}{l}\text { Connectivity } \\
\text { Use of Internet }\end{array}$}} & \multicolumn{2}{|c|}{$\$$ Human capital } \\
\hline & & \multicolumn{2}{|c|}{ Integration of digital technology } \\
\hline$\because$ Digita & ervies & & \\
\hline
\end{tabular}

\section{Source: author's calculations based on DESI by Components, 2020}

\section{Fig. 4. DESI index by components in the Baltic States}

Human capital refers to the digital skills of the population and the number of ICT professionals (DESI by Components, 2020). Both indicators are needed in the digital transformation process. This trend is in line with the trend in Estonia's higher spending on R\&D and tertiary education. There is an evident correlation between the DESI index and the e-government and e-participation indices. Although Latvia demonstrates the lowest DESI index, it shows the highest Connectivity component, which refers to the uptake of fixed and mobile broadband services. However, as the cases of Estonia and Lithuania show, other factors, such as a clear policies and skills and competencies of political leaders and citizens, may play a greater role in driving the digital transformation process and adopting blockchain technology in various areas of potential application.

As figure 5 shows, Estonia has the highest GDP per capita among three countries, which can be explained by cost savings and efficiencies supported by higher e-government and e-participation indices, 
as well as more digitalized economy through facilitating digitally oriented support measures, including adoption of blockchain technology.

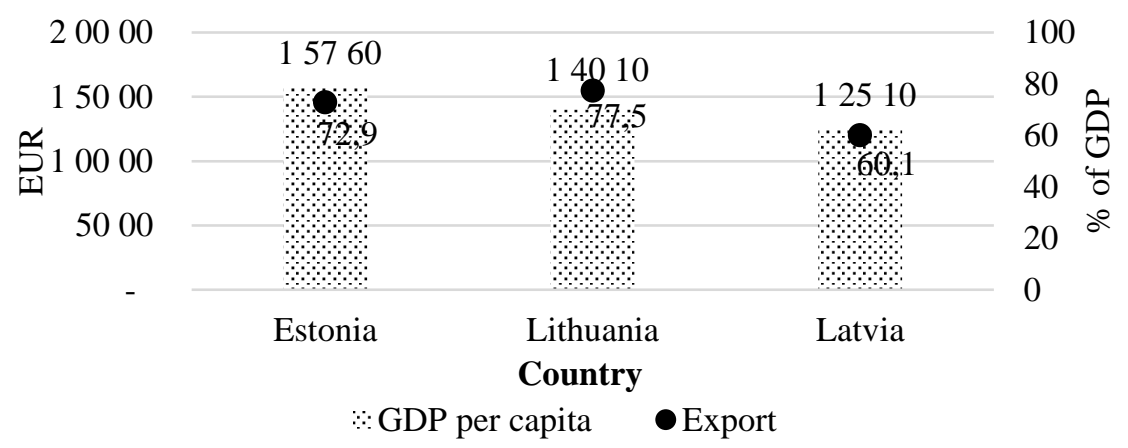

Source: author's calculations based on Exports of Goods..., 2019; Real GDP per Capita, 2019

Fig. 5. Real GDP per capita and exports as \% of GDP in the Baltic States

Lithuania shows the highest level of exports among the Baltic states, which can be explained by the determined action of Lithuanian policy makers in attracting global technology companies, especially in the field of fintech, where it is common to utilize modern technologies, including various blockchain-based solutions. Consequently, various technology enterprises, that promote fintech solutions, contribute to technological exports, taking into account that fintech solutions are often targeted at global markets. Also, additional jobs are created in the local market as foreign companies require local talent to develop and promote various fintech solutions that stimulates economic growth. Thus, adoption of blockchain technology likely has a direct and indirect impact on GDP and exports.

\section{Conclusions, proposals, recommendations}

1) Estonia is the leading country in the Baltic States measured by the majority of regional competitiveness indicators, which is supported by its pioneering approach and higher levels of adoption of blockchain technology among three countries.

2) Latvia significantly lags behind Lithuania and Estonia in terms of regional competitiveness and adoption of blockchain technology, which is weakened by the regulatory unclarity for virtual asset service providers and the lack of supportive actions from the government for blockchain innovation and its further adoption within and beyond crypto-space.

3) The author concludes that the reason for Latvia's technological backwardness in comparison to Estonia and Lithuania are due to the reasons described below:

- Lack of blockchain competencies of employees at ministries and government agencies, especially referring to the development of appropriate economic, governance and cooperation models for blockchain technology adoption.

- A rambling approach to blockchain experimentation instead of a strategic vision within the view of overall digital transformation of a country, considering integrations with other technological priority directions and associated impact on the national economy.

- Lack of initiative by government institutions to consult with blockchain experts or to contract a preparation of a comprehensive study on adoption of blockchain technology within the national economy to professional service providers.

- Lack of initiative of the Latvian Blockchain Association to get involved in public policy consultation processes. 
4) Estonia's and Lithuania's experiences in adopting blockchain technology in the fields of egovernment and fintech, respectively, can serve as a foundation for Latvian policy makers to define and implement relevant supporting actions for blockchain adoption in Latvia.

\section{Acknowledgement}

Preparation of the paper was supported by project 'Latvian state and society challenges and their solutions in the international context (INTERFRAME-LV)' of State Research Program 'Latvian Heritage and Future Challenges for National Sustainability'.

\section{Bibliography}

1. About Us [n.y.]. Retrieved: https://bcgateway.eu/about-us/ Access: 12.09 .2020

2. Adamonis, A. (2020). LBChain: Reaching the Finish Line and What's Next? Retrieved: https://www.youtube.com/ watch?v=xGIGoUdkHFU\&feature=youtu.be Access: 16.09 .2020

3. A Digital Single Market Strategy for Europe: EU Strategy (2015). Retrieved https://eur-lex.europa.eu/legalcontent/EN/TXT/?uri = celex\%3A52015DC0192 Access: 15.11.2021

4. Bitnation to Offer Blockchain Notary Services for Estonia's e-Residents (2015). Retrieved: https://www.coinspeaker.com/estonia-teams-up-with-bitnation-to-launch-e-residency-blockchain-program/ Access: 18.10.2020

5. Blockchain Regulations (2020). Blockchain Consultus. Retrieved: https://www.blockchainconsultus.io/regulations/ Access: 21.08.2020

6. Country Data (2020). UN E-Government Knowledgebase. Retrieved: https://publicadministration.un.org/egovkb/en-us/Data-Center Access: 19.10.2020

7. DESI by Components (2020). European Commission. Retrieved: https://digital-agenda-data.eu/charts/desicomponents \#chart $=\{\% 22$ indicator $\% 22: \% 22$ desi $\% 22, \% 22$ breakdown-group $\% 22: \% 22$ desi $\% 22, \% 22$ unitmeasure\%22:\%22egov_score\%22,\%22time-period\%22:\%222020\%22\} Access: 03.01 .2021

8. Davidson, S., de Filippi, P., Potts, J. (2018) Blockchains and the Economic Institutions of Capitalism. Journal of Institutional Economics, Vol. 14(4), Cambridge University Press, pp. $639-658$.

9. Digital Collector Coin (LBCoin) (2020). Bank of Lithuania. Retrieved: https://www.lb.It/en/digital-collectorcoin-Ibcoin Access: 12.11.2021

10. Ekonomikas Ministrija (2019). Informativais zinojums 'Par blokkedes tehnologiju izmantosanas piemeriem, perspektivam un talako ricibu jomas attistibas veicinasanai'. Retrieved: http://tap.mk.gov.lv/lv/mk/tap/?pid=40469165\&mode =mk\&date=2019-02-26 Access: 12.10 .2021

11. Ekonomikas Ministrija (2020). Informativais zinojums 'Par blokkedes tehnologijas izmantosanas iespejam kases aparatos un citas ierices enu ekonomikas mazinasanas nolukos'. Retrieved: http://tap.mk.gov.lv/lv/mk/tap/?dateFrom=2019-06-20\&dateTo=2020-0619\&text=blok\%C4\%B7\%C4\%93d\&org=0\&area=0\&type=0 Access: 12.10 .2021

12. Estonian Financial Intelligence Unit (2020). A Survey of Service Providers of Virtual Currency. Retrieved: https://www. politsei.ee/files/Rahapesu/ENG/estonian-fiu-survey-of-service-providers-of-virtual-currency-3010-2020.pdf?c0acfba2ff Access: 12.11.2020

13. European Blockchain Strategy (2021) European Commission Retrieved: https://ec.europa.eu/digital-singlemarket/en/news/european-blockchain-strategy-brochure Access: 11.01.2021

14. European Parliament (2017). Notice to Members: Report on the IMCO Mission to Tallinn, Estonia on 19 - 21 April 2017. Retrieved: https://www.europarl.europa.eu/doceo/document/IMCO-CM-605929_EN.pdf?redirect Access: 12.10 .2020

15. Exports of Goods and Services in \% of GDP (2019). Eurostat. Retrieved: https://ec.europa.eu/eurostat/databrowser/product/page/TET00003 Access: 16.01.2021

16. Finansu Ministrija (2018). Informativais zinojums 'Par virtualo valutu izmantosanas ieguvumiem un riskiem, un talako ricibu jomas attistibas veicinasanai un identificeto risku mazinasanai'. Retrieved: http://tap.mk.gov.lv/mk/tap/?pid=40461133 Access: 21.10 .2020

17. Govina, J. (2018). Jekaterina Govina, Bank of Lithuania Speech at the Blockchain panel. Retrieved: https://www.youtube.com/watch?v =bQZwpP_yo64 Access: 21.09.2020

18. Gross Domestic Expenditure on Research and Development (R\&D) (2019). Eurostat. Retrieved: Access: https://ec.europa.eu/eurostat/databrowser/product/page/TIPSST10 Access: 28.01.2021

19. Iansiti, M., Lakhani, R.M. (2017). The Truth About Blockchain. Harvard Business Review, Vol 95(1). Boston: Harvard Business Press, pp. 118-127.

20. Innovation Sandbox [n.y.] Retrieved: https://www.fktk.Iv/en/licensing/innovation-and-fintech/innovationsandbox/ Access: 12.11.2020

21. LBChain (2020). Bank of Lithuania. Retrieved: https://www.lb.It/en/lbchain Access: 12.09.2020

22. List of All Cryptocurrency Exchanges (2020). Blockspot Retrieved: https://blockspot.io/exchange/ Access: 19.08.2020 
23. Public Expenditure on Education by Education Level and Programme Orientation - as \% of GDP (2017). Eurostat. Retrieved: https://ec.europa.eu/eurostat/databrowser/product/page/EDUC_UOE_FINE06 Access: 12.10.2020

24. PwC (2019). Estonia - the Digital Republic Secured by Blockchain Retrieved: https://www.pwc.com/gx/en/services/legal/tech/assets/estonia-the-digital-republic-secured-byblockchain.pdf Access: 15.09.2020

25. Real GDP per Capita (2019). Eurostat. Retrieved: https://ec.europa.eu/eurostat/databrowser/product/page/SDG_08_10 Access: 28.01.2021

26. Rukovoditel' blokchejn-centra: skoro nasha tehnologija budet tak zhe privychna, kak i internet (2018). Retrieved: http://novayagazeta.ee/articles/21148/ Access: 19.11.2020

27. Security and Safety. KSI Blockchain [n.y.]. Retrieved: https://e-estonia.com/solutions/security-andsafety/ksi-blockchain Access: 12.09.2020

28. Stats and Facts (2020). ICOBench. Retrieved: https://icobench.com/stats Access: 13.08 .2020

29. The New Digital Nation [n.y.] Retrieved: https://e-resident.gov.ee/ Access: 19.08 .2020

30. Wintjes R., Hollanders H. (2020) The Regional Impact of Technological Change in 2020 Retrieved: https://ec.europa.eu/regional_policy/sources/docgener/studies/pdf/2010_technological_change.pdf Access: 15.09.2020

31. Yli-Huumo, J., Ko, D., Choi, S., Park, S., \& Smolander, K. (2016) Where is Current Research on Blockchain Technology? - A Systematic Review. PLOS One, Vol. 11(10), pp. 1-27. 